\title{
The History of Entrepreneurship
}

in Mexico 
Required reading for those that wish to understand entrepreneurship in Mexico. It provides a realistic, practical and down-to-earth understanding of structures, processes, and cultures associated with effective entrepreneurship specific to Mexico.

Mark Clark, PhD, Director-Prelims MPrelimscNair Center for Entrepreneurship and Free Enterprise Program Coordinator - Master of Science, Management and Entrepreneurship Finalist - 2019 Opal Goolsby Outstanding Professor Award Faculty Sponsor-AMA@HBU (Learn, Lead, Innovate)

This is an important book storytelling entrepreneurial identity, its grounding in the family idyll, more about, a sense of place. There are glimpses of a shift from egoistic-hero-narrative to the process of storytelling of place, in which entrepreneurs struggle to gain legitimacy for partners to invest capital needed to mobilize their projects by being part of their community. Mexico's entrepreneurial partners prefer knowing each other's families, attending the same school, and growing up in the same place. Grounding entrepreneurship in the storytelling of place, community, and family makes all the difference to sustaining effective practice.

David M. Boje, Professor Emeritus, New Mexico State University, Professor, Aalborg's University, Business College, Denmark

This book responds to research calls for contextualizing entrepreneurship in emerging economies and developing countries and invites us to understand the field of entrepreneurship in Mexico better. The book gathers Mexican contributors, who are mostly based in Mexican universities, researching entrepreneurship in Mexico. The chapters in this book include descriptive studies, applied research, as well as case studies. The chapters help build awareness of the practice of entrepreneurship across industries, clusters, urban and rural places, as well as individuals' backgrounds. The chapters also analyzes public policies and programs developed over time. The book is a valuable tool to study how institutional frameworks at the micro-, meso-, and macro- levels shape the Mexican entrepreneurial spirit.

Marcela Ramírez-Pasillas, PhD, Assistant Professor, Jönköping International Business School, Jönköping University

The History of Entrepreneurship in Mexico has moved thinking forward in an important, but understudied topic - entrepreneurship in Mexico. Drs. Oscar Javier Montiel Mendez and Araceli Almaraz have brought together the cuttingedge perspectives of twenty Mexican scholars from distinguished universities 
inside and outside of Mexico who share their views on innovation, creativity, entrepreneurial diversity, business history, the impact of context on entrepreneurialism, and of course the process of entrepreneurship. The History of Entrepreneurship in Mexico, a rare compendium, will become a comprehensive, important, and valuable resource for scholars and students around the world.

Mary B. Teagarden, PhD, Associate Dean of Faculty and Administration, Professor of Global Management, Editor of Thunderbird International Business Review, Editor of Journal of International Business Studies, Thunderbird School of Global Management, Arizona State University 
This page intentionally left blank 


\section{The History of Entrepreneurship in Mexico: Contextualizing Theory, Theorizing Context}

\section{EDITED BY}

ARACELI ALMARAZ ALVARADO

El Colegio de la Frontera Norte, A.C., México

OSCAR JAVIER MONTIEL MÉNDEZ

Universidad Autónoma de Ciudad Juárez, México

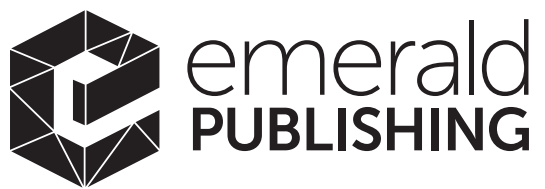

United Kingdom - North America - Japan - India - Malaysia - China 
Emerald Publishing Limited

Howard House, Wagon Lane, Bingley BD16 1WA, UK

First edition 2020

Copyright (C) 2020 Emerald Publishing Limited

\section{Reprints and permissions service}

Contact: permissions@emeraldinsight.com

No part of this book may be reproduced, stored in a retrieval system, transmitted in any form or by any means electronic, mechanical, photocopying, recording or otherwise without either the prior written permission of the publisher or a licence permitting restricted copying issued in the UK by The Copyright Licensing Agency and in the USA by The Copyright Clearance Center. Any opinions expressed in the chapters are those of the authors. Whilst Emerald makes every effort to ensure the quality and accuracy of its content, Emerald makes no representation implied or otherwise, as to the chapters' suitability and application and disclaims any warranties, express or implied, to their use.

British Library Cataloguing in Publication Data

A catalogue record for this book is available from the British Library

ISBN: 978-1-83909-172-8 (Print)

ISBN: 978-1-83909-171-1 (Online)

ISBN: 978-1-83909-173-5 (Epub)

ISOQAR certified

Management System,

awarded to Emerald

for adherence to

Environmental

standard

ISOQAR

ISO 14001:2004. 


\section{Table of Contents}

List of Figures and Graphs $\quad i x$

List of Tables $x i$

List of Contributors xiii

Introduction: Mexico and the Routes of Entrepreneurship: Beyond Traditional Discussions

Araceli Almaraz Alvarado and Oscar Javier Montiel Méndez

Chapter 1 The History of Entrepreneurship in Mexico: A View from the Academic Lens

Oscar Javier Montiel Méndez and María Guadalupe Calderón

Chapter 2 Origins of Entrepreneurship: The Other Faces of the Rhombus

Araceli Almaraz Alvarado

Chapter 3 Entrepreneurship in Mexico: Reality, Myths, and Challenges

Maribel Guerrero and Carlos Alberto Santamaría-Velasco

Chapter 4 Challenges and Perspectives of Entrepreneurship in the Regions of Mexico

Moisés Librado González and Natanael Ramírez Angulo

Chapter 5 Rural Entrepreneurship and Small Businesses in Mexico 109 Rebeca de Gortari and María Josefa Santos 
viii

Chapter 6 Sea Urchin, the Origin of an Export Venture Driven by Japanese Immigrants

Virginia Guadalupe López Torres, Luis Ramón Moreno Moreno and Mónica Lorena Sánchez Limón

Chapter 7 Cultural Milieu and Business Initiatives in Mexico's Midwest

Carlos Riojas and Angélica Basulto

Chapter 8 Footwear Cluster: A History of Entrepreneurship in Crisis

Lorena del Carmen Álvarez-Castañón

Chapter 9 Public Policies on Entrepreneurial Activity in the Mexico of the Twentieth Century

Anel Flores-Novelo, Ana Laura Bojórquez Carrillo and

María Cristina Mata Castro

Chapter 10 Epilogue: Back to the Future or Total Recall?

Bernardo Bátiz-Lazo

Index 


\section{List of Figures and Graphs}

Figure 1.1 Terms Encoded in Documents. 15

Figure 1.2 Web of Science Categories. 16

Figure 1.3 Percentage by Total of Documents Found (204). 16

Figure 1.4 Document Types. 18

$\begin{array}{lll}\text { Figure 2.1 First Cycle of Startups. } & 42\end{array}$

Figure 2.2 Interrelation of Internal and External Dimensions. 53

Figure 3.1 General Distribution of Mexican Ventures by Industry and Region, 2017.

Figure 3.2 Obstacles for Doing Business in Mexico, 2017.

Figure 3.3 The Entrepreneurial Process. 71

Figure 3.4 Evolution of Entrepreneurship Indicators, Mexico, 2001-2017. 72

Figure 3.5 Evolution of the Conditions That Foster Entrepreneurship, Mexico, 2001-2017. 73

Figure 3.6 Evolution in the Participation of Informal Economy in the GDP, Mexico, 2003-2017. 74

Figure 3.7 Evolution of Quality Indicators of the Entrepreneurial Activity, Mexico, 2001-2017. 75

Figure 3.8 Pillars of the Entrepreneurship Ecosystems, Benchmarking 2013. $\quad 76$

Figure 4.1 Entrepreneurial Regions by State, Mexico (2014). 91

Figure 4.2 From Unemployment to the Training of Entrepreneurs with a High Social Impact. 101

Graph 4.1 Entrepreneurship in Mexico by Gender. 95

Graph 4.2 Age of Entrepreneurs in Mexico (2015). 96

Graph 4.3 Age of Microenterprises in Mexico (2015). 98

$\begin{array}{lll}\text { Figure 6.1 Red Sea Urchin (Strongylocentrotus franciscanus). } & 128\end{array}$

$\begin{array}{ll}\text { Figure 6.2 World Production. } & 130\end{array}$

Figure 6.3 Sea Urchin Production. 133

Figure 6.4 Sea Urchin Fishing Locations. 135 
$\boldsymbol{x} \quad$ List of Figures and Graphs

Figure 6.5 Sea Urchin Trade Balance. 142

Figure 6.6 Sea Urchin Exports. 143

Figure 7.1 Main Urban Localities in Mexico's Midwest. 149

Figure 8.1 GDP's Contribution Trend from 1993 to 2018.

Figure 10.1 A Cloud Map of Entrepreneurship in Mexico. 221 


\section{List of Tables}

Table 1.1 Researcher's Institution. 17

Table 2.1 Internal and External Dimensions. 52

Table 2.2 Typology of the Ventures Considering External and Internal Dimensions.

Table 3.1 Position of Mexico in the International Entrepreneurship Rankings, 2014-2018.

Table 3.2 Challenges for Improving the Elements of the Mexican Entrepreneurship Ecosystem.

Table 4.1 Volume of New Enterprises by State, Mexico (1999-2014).

Table 4.2 Microenterprises According to the Type of Enterprise (2015). 96

Table 4.3 Educational Level of Entrepreneurs in Mexico. 97

Table 6.1 Population of the Main Towns of Baja California, 1900-1940.

Table 6.2 Main Fishing and Aquaculture Producing States (2014).

Table 6.3 Fishing and Aquaculture Production of Baja California in 2014.

Table 6.4 Sea Urchin Production (Tons) in Baja California (2006-2013).

Table 6.5 Sea Urchin Production Areas in Baja California, Pacific Coast.

Table 6.6 Sea Urchin Fishermen in 1990 in Baja California. 140

Table 7.1 Emblematic Enterprises in Jalisco over Time. 164

Table 8.1 Analysis of Productivity Indexes from 2005 to $2017 . \quad 181$ 
This page intentionally left blank 


\section{List of Contributors}

Araceli Almaraz Alvarado

Lorena del Carmen Álvarez-

Castañón

Angélica Basulto

Bernardo Bátiz-Lazo

Ana Laura Bojórquez Carrillo

María Guadalupe Calderón

Anel Flores-Novelo

Rebeca de Gortari

Maribel Guerrero

Moisés Librado González

María Cristina Mata Castro

Luis Ramón Moreno Moreno
El Colegio de la Frontera Norte A.C., México

Universidad de Guanajuato, México

Universidad de Guadalajara, CUCEA, México

Bangor University, UK

Universidad Autónoma de Yucatán, México

Universidad Autónoma

Metropolitana, Cuajimalpa, México

Universidad Autónoma de Yucatán, México

School of Business and Economics, Universidad del Desarrollo, Chile/ Newcastle Business School, Northumbria University, UK

School of Business and Economics, Universidad del Desarrollo, Chile; and Newcastle Business School, Northumbria University, UK

Universidad Autónoma de Baja California, México/Universidad de Castilla La Mancha, Spain

Universidad Autónoma de Yucatán, México

Universidad Autónoma de Baja California, México 
Oscar Javier Montiel Méndez Universidad Autónoma de Ciudad Juárez, México

Natanael Ramírez Angulo Universidad Autónoma de Baja California, México/Universidad de Castilla La Mancha, Spain

Carlos Riojas Universidad de Guadalajara, CU Ciénega, México

Mónica Lorena Sánchez Limón Universidad Autónoma de Tamaulipas, México

Carlos Alberto Santamaría-Velasco Universidad de Guadalajara, CUValles, México

María Josefa Santos Universidad Nacional Autónoma de México, Instituto de Investigaciones Sociales, México

Virginia Guadalupe López Torres Universidad Autónoma de Baja California, México 